\title{
An outbreak of rotavirus infection in a long-stay ward of a geriatric hospital
}

\author{
W D CUBITT AND H HOLZEL
}

From the Public Health Laboratory and Department of Microbiology, Central Middlesex Hospital, London NW10, UK

SUMMARY An outbreak of rotavirus infection in elderly patients in a long-stay ward of a geriatric hospital is described. Virus was detected in 7/15 (47\%) symptomatic individuals. Four members of staff were among those affected. The findings emphasise the need for electron microscopy to be used in the initial investigation of outbreaks of diarrhoea in all age groups.

In a recent study ${ }^{1}$ we investigated a hospital outbreak of rotavirus infection which occurred in adults in a cardiology ward. Patients and members of the staff were affected, and strict isolation procedures were required to bring the outbreak under control.

This report describes a further outbreak of rotavirus infection involving adults in hospital. The incident took place in the long-stay ward of a geriatric hospital in north-west London in which no facilities for isolation were available. Members of the staff and patients were again affected.

\section{The wards}

The unit consisted of two wards of the Nightingale design, one for male the other for female patients, separated by offices for the nursing staff. Each ward contained a lounge area, and a separate small lounge was available for the more mobile individuals. Toilet facilities were provided for each of the wards but the majority of patients were unable to help themselves, and commodes and disposable bedpans were usually used and bowls were provided for handwashing. As the workload on this unit was heavy, care was taken to keep the wards well-staffed, and both wards were clean and well maintained.

\section{The outbreak}

The outbreak occurred during a three-week period in March 1979. The first case was believed to have been an 81-year-old uraemic man who developed diarrhoea on 7 March and died a week later. Subsequently, 10 patients (aged between 65 and 90 years) and four members of the nursing staff

Received for publication 17 July 1979 developed nausea and diarrhoea which consisted of one or two loose stools per day. Symptoms lasted for two to seven days and were generally mild. In contrast, severe illness has been noted by other workers in a small number of adults. 23

When rotavirus was established as the likely cause of symptoms the ward was closed to admissions, and staff movement from this unit to other wards was discontinued. The unit was reopened 12 days after the onset of symptoms in the last case.

\section{Laboratory investigations}

After routine bacteriological examination of samples from symptomatic individuals had failed to reveal a causative agent, specimens were referred to us for screening by electron microscopy. Samples from all the patients and staff on this unit were examined for the presence of rotavirus. Serial samples were obtained from all individuals found to be excreting rotavirus and from any patient who subsequently developed symptoms. The screening procedure was repeated 10 to 12 days after the onset of symptoms in the last case.

\section{Results}

During the outbreak, specimens from all individuals on the affected wards (22 patients and 17 members of staff) were examined for the presence of rotavirus (Table 1). Virus was detected in samples from seven $(46.6 \%)$ of 15 symptomatic individuals, including the 26-year-old ward sister. None of the 27 asymptomatic individuals was found to be excreting virus when initially screened, but three of these (two females and one male) subsequently developed diarrhoea with concurrent rotavirus excretion. 
Table 1 Detection of rotavirus in patients and staff

\begin{tabular}{llll}
\hline & $\begin{array}{l}\text { Patients } \\
(65-90 \text { years })\end{array}$ & $\begin{array}{l}\text { Staff } \\
(20-40 \text { years })\end{array}$ & Total \\
\hline Individuals examined & 22 & 17 & 39 \\
Number with symptoms & 11 & 4 & 15 \\
Number with rotavirus & 6 & 1 & 7 \\
\hline
\end{tabular}

Rotavirus was not detected from any asymptomatic individuals

Final screening of both patients and staff 10 to 12 days after the occurrence of the last case showed that rotavirus was no longer present.

\section{Discussion}

In a previous report ${ }^{1}$ we suggested that rotavirus may cause outbreaks of diarrhoea in adults and that patients of the 60-90 year age group are particularly at risk. This theory is supported by the results of antibody studies in different age groups ${ }^{4}$ which demonstrate the continuing fall in antibody to rotavirus after 3 years of age. This new outbreak, in which symptoms were again confined to patients over 60 years of age, lends further support to this view. In both episodes (Table 2) there was a noticeably higher attack rate among female patients. In hospital 1 (Table 2) the difference in attack rates was significant $(0.02>P>0.01)$, although in the second episode this was not apparent $(0.1>P>0.05)$. These findings are consistent with a lower level of immunity in females of this age group, a finding supported by the work of others. ${ }^{4} 5$ The antibody response of adults involved in this outbreak of rotavirus infection is being investigated at the present time. A further point of interest is the involvement in each episode of several younger members of the staff (aged 20-30 years), a fact of great importance in the management of such outbreaks. In the control of both these episodes staff movement to other wards was restricted, but further management was influenced by the very different environments in which they took place. In the geriatric hospital the lack of isolation facilities necessitated the closure of the unit to admissions. This was possible only because patient turnover was extremely low. With the use of these measures the outbreak lasted for a period of three weeks, which is likely to have been its natural duration. In contrast, the previous outbreak took place in a unit that was not closed as it had a high case turnover consisting of acute medical emergencies. This unit had ideal isolation facilities and when these were used the outbreak was halted within two weeks, although throughout this time admissions to the unit continued.

Our findings from these two studies strongly suggest that rotavirus infection is an important cause of outbreaks of diarrhoea in adults in closed communities and demonstrate that appropriate control measures can limit the extent of such outbreaks. As a result of our interest in illness in the 60 plus age group, we have detected several further outbreaks of rotavirus infection in adults in hospitals in north-west London in which the severity of illness ranged from very mild symptoms to severe vomiting and diarrhoea resulting in a protracted stay in hospital. These findings indicate that, contrary to popular belief, spread of rotavirus among adults is not an uncommon event.

We thank Sir Robert Williams and Dr D A McSwiggan for advice and criticism and we acknowledge the help and cooperation of Dr P J Sanderson and Sister $\mathbf{J}$ Church in providing epidemiological data.

\section{References}

${ }^{1}$ Holzel H, Cubitt W D, McSwiggan D A, Sanderson P J, Church J. An outbreak of rotavirus infection among adults in a cardiology ward. $J$ Infect 1980; in press.

${ }^{2}$ Ørstavik I, Haug K W, Søvde A. Rotavirus-associated gastroenteritis in two adults probably caused by virus reinfection. Scand J Infect Dis 1976; 8: 277-278.

${ }^{3}$ Von Bonsdorff $\mathrm{C} \mathrm{H}$, Hovi T, Måkelå P, Hovi L, Tevalvoto-Aarnio M. Rotavirus associated with acute

Table 2 Two outbreaks of rotavirus infection in adults

\begin{tabular}{|c|c|c|c|c|c|c|}
\hline & \multicolumn{3}{|l|}{ Hospital I* } & \multicolumn{3}{|l|}{ Hospital 2} \\
\hline & Symptoms & Asymptomatic & Total & Symptoms & Asymptomatic & Total \\
\hline $\begin{array}{l}\text { Male } \\
\text { Female }\end{array}$ & $\begin{array}{l}5 \\
5\end{array}$ & $\begin{array}{r}12 \\
2\end{array}$ & $\begin{array}{r}17 \\
7\end{array}$ & $\begin{array}{l}5 \\
6\end{array}$ & $\begin{array}{l}8 \\
3\end{array}$ & $\begin{array}{r}13 \\
9\end{array}$ \\
\hline Total & 10 & 14 & 24 & 11 & 11 & 22 \\
\hline
\end{tabular}

Difference in female/male attack rates (chi-square test with Yates' correction)

Hospital $1 \quad x^{2}=5.53 \quad 0.02>P>0.01$

Hospital $2 \quad x^{2}=3.01 \quad 0.1>P>0.05$

* Outbreak in hospital 1 described in reference 1 . 
gastroenteritis in adults (Letter). Lancet 1976; $2: 423$.

${ }^{4}$ Elias M M. Distribution and titres of rotavirus antibodies in different age groups. J Hyg Camb 1977; 79: 365-372.

${ }^{5}$ Tufvesson B, Johnsson T, Persson B. Family infections by reo-like virus, comparison of antibody titres by complement fixation and immunoelectroosmophoresis.
Scand J Infect Dis 1977; 9: 257-261.

Requests for reprints to: W D Cubitt, Public Health Laboratory, Department of Microbiology, Central Middlesex Hospital, Park Royal, London NW10 7NS, UK.

\section{The February 1980 issue}

\section{THE FEBRUARY 1980 ISSUE CONTAINS THE FOLLOWING PAPERS}

On the histological diagnosis and prognosis of malignant melanoma ARNOLD LEVENE

Use of morphometry and immunohistochemistry of small intestinal biopsy specimens in the diagnosis of food allergy PCM ROSEKRANS, CJLM MEIJER, CJ CORNELISSE, AM Vd WAL, AND J LINDEMAN

A comparative trial of liver biopsy needles MC BATESON, D HOPWOOD, HLD DUGUID, AND IAN AD BOUCHIER

Basal cell carcinoma arising in a smallpox vaccination site JD RICH, BF SHESOL, AND DW HORNE, III

Abnormal chromosomal marker $\left(D_{14} q+\right)$ in a patient with alpha heavy chain disease U GAFTER, E KESSLER, F SHABTAY, P SHAKED, AND M DJALDETTI

Evaluation of the Honeywell ACS 1000 leucocyte differential counter MARGARET CLOWES, C GILES, RM IBBOTSON, AND PH JOHNSON

Sex and acid phosphatase in childhood non-T lymphoblastic leukaemia JS LILLEYMAN, JA BRITTON, BJ LAYCOCK, AND PJ SUGDEN

Post-transfusion survival of hydroxyethyl starch 450/0.70 in man: a long-term study JOHN MILTON MISHLER, COLIN R RICKETTS, AND EDWARD J PARKHOUSE

Substance $\mathbf{P}$ in ovarian carcinoid $\mathbf{P}$ SKRABANEK, P DERVAN, D CANNON, AND D POWELL

Serum $\alpha_{2}$-macroglobulin levels in diabetes K JAMES, J MERRIMAN, RS GRAY, LJP DUNCAN, AND R HERD

A method for the estimation of the activity of the inhibitor of the first component of complement

AM SMITH AND RA THOMPSON Book reviews
Copies are still available and may be obtained from the PUBLISHING MANAGER, BRITISH MEDICAL ASSOCIATION, TAVISTOCK SQUARE, LONDON WC1H 9JR, price $£ 3.00$, including postage
Indirect micro-immunofluorescence test for detecting type-specific antibodies to herpes simplex virus T FORSEY AND S DAROUGAR

A comparison of the sensitivity of immunofluorescence and Giemsa for staining Chlamydia trachomatis inclusions in cycloheximide-treated McCoy cells PE MUNDAY, AP JOHNSON, BJ THOMAS, AND D TAYLOR-ROBINSON

A regional programme to collect plasma for preparation of human immunoglobulin anti-rabies RJ CRAWFORD, M MORGAN, AND R MITCHELL

Diagnostic value and biological significance of antibody-coated bacteria in urine $C$ MENGOLI, E AROSIO, D BONATO, G SPIAZZI, P PANCERA, G MONTESI, A LECHI, AND LA SCURO

Serious infection caused by group $C$ streptococci ATM GHONEIM AND E MARY COOKE

Enterovirus typing by immune electron microscopy using low-speed centrifugation NK NARANG AND AA CODD

A technique avoiding carcinogens for the demonstration of myeloperoxidase in blood and bone marrow smears BJ LAYCOCK, JA BRITTON, AND JS LILLEYMAN

A rapid simplified method for plasma 25-hydroxyvitamin D estimation JUDITH C HAMILTON

Letters to the Editor

Book reviews

\section{Technical methods}

